prejudice of speciesism lies not in the fact that marginal humans are treated better than animals but in valuing typically superior human intelligence so highly that the interests and suffering of animals are considered morally insignificant in comparison to those of humans, which is to say normal humans. He thus focuses on the issue of animal suffering, which is the motivating concern of animal advocates, and the moral insignificance of animals' supposedly inferior intelligence as an excuse for not taking their suffering seriously. This analysis suggests characterizing speciesism in a rather different way than either of the two definitions Evelyn has given us. Such a characterization might run as follows:

a speciesist doctrine is one which gives such great moral importance to what typically distinguishes one species from others that it leads to disregarding the interests of those others in favor of satisfying the interests of members of the favored species.

If we start by presuming that the interests of others should not (prima facie) be disregarded, then the burden of proof is clearly on those who maintain a speciesist doctrine to demonstrate why it is not a prejudice. And I think that in contemporary, Western society we do start with that presumption, since the idea that animals should not be treated cruelly is a commonplace today, the controversy thus being not over whether animals are morally considerable at all but more specifically over what sorts or degrees of moral status they have and what sorts or degrees of moral responsibility or obligation we have to them. It follows that the question of whether speciesism is a prejudice covers a whole range of questions: does our characteristically superior intelligence justify our routinely killing animals for entertainment or meat, justify our routinely imprisoning them for amusement or profit, justify our routinely making them sick to cure our ills, and so forth. I think that the answer to those questions is "No," which is why, no matter what one concludes about our preferential treatment of marginal humans, I agree with Evelyn that speciesism is a prejudice.

Notes

1. See "Moral Community and Animal Rights," American Philosophical Quarterly 17 (1980), pp. 45-52, or Morals. Reson and Animals (Philadelphia: Temple University Press, 1987), Chapter 8.

2. (New York: Avon Books, 1975), pp. 69.

\section{ON THE \\ RELEVANCE \\ OF MARGINAL \\ HUMANS: \\ A Reply To Sapontzis}

\section{Evelyn Pluhar}

I couldn't agree more with Professor Sapontzis' contention that the root of human willingness to sacrifice nonhuman animals is the assumption that our "superior" mental abilities license the exploitation of so-called "lesser" beings. The "untutored" view is shared by mainstream ethical theorists, who hold that autonomous moral agents ('persons' in the strictest sense of that term) are the primary possessors of basic moral rights. I pointed this out at the beginning of this paper,

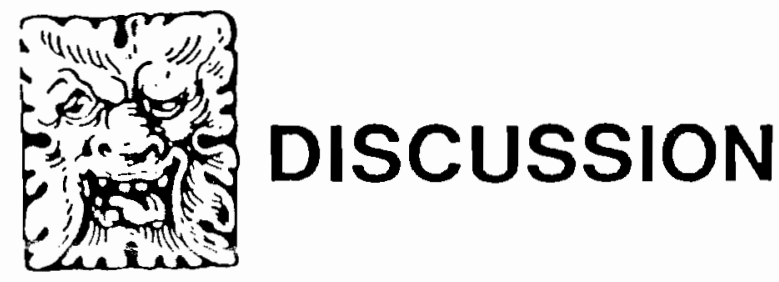


and I have argued about this assumption at length elsewhere. ${ }^{1}$ Steve's commentary further underlines this very important point. However, I disagree with his claim that our treatment of human nonpersons ("marginal" humans) is irrelevant to the issue of whether speciesism is a bigoted or a justified view.

Steve offers several reasons to justify his claim that marginal human are not "where the action is." The most important is his charge that I locate " the fault" or "the prejudice" in speciesism as the inconsistent treatment of human and nonhuman nonpersons instead of in the assumption that the personhood which characterizes our species is of paramount moral importance. I have a two-part reply here. First, this is a false dilemma. I do happen to believe that the personhood assumption or criterion is mistaken. But surely it is also mistaken to treat beings whe, on one's own view, have the same moral status, in morally dissimilar ways. The recent defenders of speciesism certainly take the charge of inconsistency extremely seriously, as well they should; they devote all their energies to defeating it (unsuccessfully, as I

argue). Second, the focus of this paper is speciesism. Speciesism as such is the view that a right to life or preferential treatment may be accorded on grounds of species, i. e., that otherwise morally similar beings may be treated differentially for that reason. Although it may at bottom be a prejudiced view, the assumption that persons are the primary possessors of basic moral rights is not in itself speciesist. Hence, my concern in this paper is to show that recent defenders of speciesism, who try to forge links between the personhood assumption and nonpersons belonging to personhood-characterized species, fail to justify our radically different treatment of human and nonhuman persons. How could this be irrelevant to the question of whether speciesism can be justified?

Contrary to what Steve suggests, I do not believe that those of us who think the treatment of marginal humans is relevant to this issue have strayed from the original concept of speciesism. Peter Singer, in the very chapter of Animal Liberation to which Steve refers us, describes as "irredeemably speciesist" those who "while distinguishing sharply between humans and other animals .... allow no distinctions to be made within our own species, objecting to the killing of the severely retarded and the hopelessly senile as strongly as they object to the killing of normal adults." 2 $\mathrm{He}$ goes on to present a version of what we have come to call the argument from marginal cases, the very argument to which speciesists know they must respond.

The argument from marginal cases is often combined with the charge that speciesism is analogous to racism and sexism. In this context, the analogy must not be and never has been presented as thoroughgoing. No nonspeciesist would ever compare blacks or women to mentally deficient white men. The point of the analogy is that it is wrong to treat

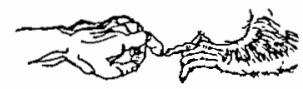

beings whom one regards as morally similar, be they human or nonhuman nonpersons, or women and men, or blacks and whites, in morally dissimilar ways. The burden is on speciecists to show that their view does not belong in this group. However, after one has argued that the right to life is not restricted to persons or to members of personhoodcharacterized species, it becomes appropriate to raise the analogy between speciesism and racism/sexism in a much more general way, for one would then be entitled to say that normal humans and many other beings are morally similar. In the face of this, continued preference for humans at the expense of others would be just as bigoted, in all respects, as racism or sexism. Current defenders of speciesism can hardly be impressed by this moral general analogy, of course, since it merely begs the question against them. The more restricted analogy which can be drawn in conjuction with the argument from marginal cases has much more sting. 
Would we be more successful in making a case for nonhuman rights if we redefined 'speciesism' along the lines Steve proposes and then attacked it? I do not think so. Steve's version of speciesism, which entails that the interests of those who don't belong to the "right" species may simply be disregarded to satisfy members of the favored species, is much easier to counter than the view which I have been attacking. The limitations of this "straw speciesism" are well-illustrated in Thomas Young's article on the killing of animals. He too defines speciesism in terms of disregarding interests merely on species grounds. That is why he refuses to call himself a speciesist, holding as he does that it would be wrong to inflict gratuitous pain on nonhumans. ${ }^{3}$ Yet, as I discussed, he proceeds to defend a view, clearly speciesist in my (and Singer's) sense, which "justifies" the routine painless killing of healthy nonhumans (but not human nonpersons). I have a difficult time thinking of such a view as a triumph for "nonspeciesist thinking!" No, we should continue to battle the strongest position our opponents have to offer us.

I agree with Steve that it would be ghastly if the goal of refuting speciesist arguments were to induce moral consistency merely for its own sake. Those of us who reject the exploitation of nonhumans have no wish to see sentient marginal humans in laboratory cages or feedlots. The goal is to make speciesists realize that something is dreadfully wrong with their initial assumptions about the treatment of nonhumans, and in my experience that is the usual result. The few who, like Frey, conclude instead that vivisection of sentient marginal humans must be permissable, must be confronted in additional ways. The argument from marginal cases is insufficient to carry the whole burden of the case for nonhuman rights, as I have argued elsewhere. ${ }^{4}$ However, this does not alter the fact that dismantling the speciesists' case for continuing to treat nonhuman and human nonpersons in radically different ways removes a major excuse for continued exploitation of nonhumans. The other side of this coin is that failure to answer their arguments contributes to that exploitation.

We are all opposed to unjustified suffering and death. That is why it is imperative to determine whether speciesism is justified. Showing that it isn't is deadly serious business, not "an abstract intellectual game." If we are ever to get anywhere in securing nonhuman animals their due, it can only be by having justification on our side.

\section{NOTES}

1 See my "Moral Agents and Moral Patients," BETWEEN THE SPECIES 4(1), 1988, pp.32-45.

2 Peter Singer, Animal Liberation (New York: Avon Books, 1975), Chapter 1, p. 20.

3 Thomas Young, "The Morality of Killing Animals: Four Arguments," ETHICS AND ANIMALS V (4), 1984, pp. 88-101. Se my footnote 33 in "Speciesism: A Form of Bigotry or a Justified View?"

4 "The Personhood View and the Argument from Marginal Cases," PHILOSOHPICA 39, 1987 (1), pp. 23-28.

\section{LABORATORY RABBIT \\ A sOLJ coouly}

Oh mourn for me when I an dead;

When having heard the executioner's bell

Give tocsin to the lab. that $I$ an fled

From your vile cage, with vilest worms to dwell.

hay think upon your foul and evil blow,

How soon ary grace and swiftress are decayed;

Stabbed ance with antigen and bending low

$I$ raised the titre high to give you aid.

What theory roblied ne of my righteul place?

What paradign supplied you with excuse?

How can your scientist-henchmen so disqrace

The lest reactor to the protein's muse?

no other Lagononph can do the sane,

To match the pentapeptide at its ganel

Leo Kartman 